\title{
GCU
}

Glasgow Caledonian

University

University for the Common Good

\section{Risk management implementation in small and medium enterprises in the UK construction industry}

Rostami, Ali; Sommerville, James; Wong, Ing Liang; Lee, Cynthia

Published in:

Engineering, Construction and Architectural Management

DOI:

10.1108/ECAM-04-2014-0057

Publication date:

2015

Document Version

Author accepted manuscript

Link to publication in ResearchOnline

Citation for published version (Harvard):

Rostami, A, Sommerville, J, Wong, IL \& Lee, C 2015, 'Risk management implementation in small and medium enterprises in the UK construction industry', Engineering, Construction and Architectural Management, vol. 22, no. 1, pp. 91-107. https://doi.org/10.1108/ECAM-04-2014-0057

\section{General rights}

Copyright and moral rights for the publications made accessible in the public portal are retained by the authors and/or other copyright owners and it is a condition of accessing publications that users recognise and abide by the legal requirements associated with these rights.

Take down policy

If you believe that this document breaches copyright please view our takedown policy at https://edshare.gcu.ac.uk/id/eprint/5179 for details of how to contact us. 


\title{
RISK MANAGEMENT IMPLEMENTATION IN SMALL AND MEDIUM ENTERPRISES IN THE UK CONSTRUCTION INDUSTRY
}

\begin{abstract}
Purpose - The competition and challenges facing construction firms during the recent recession have brought risk management (RM) to the fore in people's minds. Examination of the difficulties of implementing RM in small and medium enterprises (SMEs) in the UK construction industry has been relatively untouched. The paper aims to discuss these issues.

Design/methodology/approach - As part of on-going research to facilitate RM processing aimed at improving the competitiveness of SMEs, the difficulties in RM implementation were identified through a literature review of RM implementation in SMEs. Postal questionnaire were sent to SMEs who have experience of construction management.

Findings - Of the 153 of SMEs responding, most highlighted that the main difficulty experienced is how to scale RM process to meet their requirements. None of the available standards explain the fundamental principle of applying RM to the situations that SMEs find themselves in. This difficulty is further exacerbated by a lack of management skills and knowledge in the adoption of RM tools or techniques to identify and analyse the business' risks.
\end{abstract}

Originality/value - The identified difficulties can be considered to develop a process to facilitate RM process within SMEs..

Keywords: Construction industry, UK, Risk management, Implementation, Small and medium enterprises, Risk management tools

\section{Introduction}

The highly dynamic, risky and challenging nature of the UK construction industry leads to its rather poor reputation in comparison to other industries (Wood et al., 2002). The rate of cancelled and challenged projects in this industry is among the highest of all industries (Rounds and Segner, 2011). Bowen et al. (1999) and Mills (2001) indicated that, 
organisations in the construction industry face major difficulties in meeting their projects' planned schedules in the most cost effective manner and at a desired quality.

Many authors such as Perry and Hayes (1985), Flanagan and Norman (1993), Turner (1999) and Zou et al. (2006) have highlighted that in order to attain the project objectives in terms of time, cost and quality, organisations have to implement and practice a risk management (RM) process. Studies done by Cooke-Davies (2002) and Voetsch et al. (2004) clearly stated that business' success is highly dependent upon the support of the organisation's RM process; and Rounds and Segner (2011) described it as one of the most capable areas and critical procedures that helps parties to complete projects successfully.

Professional bodies and standards in the UK construction industry such as theBritish Standard (British Standard (BS)31100, 2008) have designated RM as one of the main areas of business management process and have introduced structured principles to fit RM within organisation. Given the characteristics of small and medium enterprises (SMEs), the implementation of RM can be a complicated one which requires a wide range of skills and resources. The Association for Project Management (APM) (2013) stated that resources to support RM implementation and its continued application are unrealistic for SMEs and beyond their capability and affordability.

This paper evaluates the key difficulties in the UK construction industry through a survey which was fundamentally designed and developed based on a broad review of literature on SMEs and the key issues in the RM implementation process.

\section{Need for RM in the construction industry}

The construction industry is structured around project-based organisations (PBOs) with shortterm and temporary nature (Green et al., 2004). This type of organisations is inherently flexible and reconfigurable, capable of performing unspecific and varied tasks (Walker, 1996). PBOs support businesses to achieve success through the managing complex services, responding to fast changing markets, providing customer focused innovation, coping with technical uncertainty and offering cross-functional business expertise (Hobday, 2000). However, notwithstanding these potential advantages of the PBOs, they are confronted with a vast array of uncertainties, because of the projects' multi-functional activities with defined sets of goals, resources and time targets. 
In addition, projects in the construction industry are subject to more risks and uncertainties than other industries (Leopoulos et al., 2006). To accomplish a project from the planning stage to completion, the activities and transformation within PBOs involve complex, regularly bespoke, and include time-consuming design and costly production processes (Flanagan and Norman, 1993). Projects are based on teamwork with differently skilled and interested stakeholders, and the co-operation among them is formed around extensive, disparate and interrelated processes (Burtonshaw-Gunn, 2009). Such complexity is further increased by many external environmental factors (Gidado, 1996).

The construction industry in the UK contributes about 7 per cent of the gross domestic product and is one of the largest sectors of the UK economy with 10 per cent of total employment (Department for Business Innovation and Skills (BIS), 2013). The sector consists of contracting and sub-contracting enterprises, architects, engineering consultants, quantity surveyors, suppliers and is capable of covering a wide range of projects in building, engineering, off-shore structures and industrial plants which embrace enormous employment opportunities.

In spite of the diversity and importance of the construction industry with its inherent risks, RM has only been applied and practiced over the past few years (Rounds and Segner, 2011) and its reputation in comparison to other industries is rather weak (Chartered Institute of Building (CIOB), 2010).

\section{RM in SMEs}

In total, 99 per cent of the enterprises in the most developed countries are SMEs (OECD, 2005) and their share in the UK construction industry is considerable (BIS, 2013). The Organisation for Economic Co-operation and Development (OECD) discloses that the economic growth of the member countries is extremely dependent upon the development of SMEs and that their "productivity growth is fuelled by competitive processes in the industry which, to a large extent, is built on the birth and death, entry and exist of smaller firms" (OECD, 2005).

All enterprises need to adopt a RM strategy and methodology to identify, assess and treat risks (Verbano and Venturini, 2013). SMEs need to practice RM much more than larger organisations because they suffer from resource limitations to respond promptly to both internal and external hazards which have the potential to cause enormous losses and even 
insolvency of the organisation (Raghavan, 2005). However, SMEs to achieve a competitive edge and enhance the rate of success of their business, they need to make risky decisions and engage in risky activities so that they can protect the innovativeness of delivering projects (Vargas-Hernandez, 2011). Moreover, due to prevalence of deregulations and the liberalisation of trade, SMEs encounter more uncertainties and challenges which make the SMEs' owner-managers to consider RM as an integral part of the business management in order to keep the firms viable and productive (Yeo and Lai, 2004).

A thorough literature review on construction risk management over the period from 1991 to 2014 (Table I) indicated that the challenge regarding the implementation of RM among organisations mainly relates to the involved people, organisation characteristics and the process of RM

Table 1. Literature on Difficulties in RM Implementation in Construction Industry

\begin{tabular}{|c|c|c|c|c|}
\hline \multirow{2}{*}{ Author } & \multirow{2}{*}{ Findings } & \multicolumn{3}{|c|}{ Difficulty Area } \\
\hline & & People & Organisation & Process \\
\hline $\begin{array}{l}\text { McKim (1991), } \\
(1992)\end{array}$ & $\begin{array}{l}\text { The reaction to risks in organisational context is not } \\
\text { always rational, and the risk behaviour of the stakeholders } \\
\text { to the construction contract is different. }\end{array}$ & $\checkmark$ & & \\
\hline Teo et al. (1991) & $\begin{array}{l}\text { Access to reliable data and information in risk } \\
\text { identification stage is a significant challenge for } \\
\text { contractors in refurbishing projects. }\end{array}$ & $\checkmark$ & & \\
\hline $\begin{array}{l}\text { Mak and Raftery } \\
\text { (1992) }\end{array}$ & $\begin{array}{l}\text { The judgmental biases of professionals in construction } \\
\text { industry affect the organisations' operating system. }\end{array}$ & $\checkmark$ & & \\
\hline Birnie (1993) & $\begin{array}{l}\text { Professionals in construction organisations make decisions } \\
\text { to use RM based on understanding the process which } \\
\text { forms their behaviour. }\end{array}$ & $\checkmark$ & & \\
\hline Bowen (1993) & $\begin{array}{l}\text { There are discrepancies between parties' perceptions in a } \\
\text { project which cause internal and combination risks within } \\
\text { the project team. }\end{array}$ & $\checkmark$ & & \\
\hline $\begin{array}{l}\text { Liu and Cheung } \\
\text { (1994) }\end{array}$ & $\begin{array}{l}\text { Different attitudes of parties in a construction project } \\
\text { produce an undesirable bias into project decision-making. }\end{array}$ & $\checkmark$ & & \\
\hline Raftery (1994b) & $\begin{array}{l}\text { An explicit RM process could provide more benefits } \\
\text { through understanding intellectual processes of decision- } \\
\text { making. }\end{array}$ & & & $\checkmark$ \\
\hline Chapman (1994) & $\begin{array}{l}\text { Management/Professionals difficulty to understand the } \\
\text { rational and formal process of RM in new projects. }\end{array}$ & $\checkmark$ & & \\
\hline Mak (1995) & $\begin{array}{l}\text { The use of probabilistic estimating and simulation in risk } \\
\text { analysis are precise but not necessarily accurate as } \\
\text { simplification and many assumptions are used. }\end{array}$ & & & $\checkmark$ \\
\hline Couillard (1995) & $\begin{array}{l}\text { Risk management success highly depends on team } \\
\text { communication and project goal understanding, and } \\
\text { correlates with experience and knowledge in terms of } \\
\text { project management. }\end{array}$ & $\checkmark$ & & \\
\hline Pasquire (1996) & $\begin{array}{l}\text { Difficulty to practise and understand the statistical } \\
\text { techniques in risk analysis. }\end{array}$ & $\checkmark$ & & $\checkmark$ \\
\hline $\begin{array}{l}\text { Amos and Dent } \\
(1997)\end{array}$ & $\begin{array}{l}\text { Management barriers associated with experience and skills } \\
\text { prevent organisations of practising formal RM systems }\end{array}$ & $\checkmark$ & & \\
\hline
\end{tabular}




\begin{tabular}{|c|c|c|c|c|}
\hline & with analytical approaches in assessing risks. & & & \\
\hline $\begin{array}{l}\text { Akintoye and } \\
\text { MacLeod (1997) }\end{array}$ & $\begin{array}{l}\text { Construction professionals have difficulty to use risk } \\
\text { management techniques for: lack of familiarity with the } \\
\text { techniques; lack of knowledge; absence of data in } \\
\text { identification phase and intangible benefits. }\end{array}$ & $\checkmark$ & & \\
\hline $\begin{array}{l}\text { kim and Bajaj } \\
(2000)\end{array}$ & $\begin{array}{l}\text { Unfamiliarity with techniques, intangible benefits and lack } \\
\text { of expertise in techniques are the main three barriers for } \\
\text { RM implementation. }\end{array}$ & $\checkmark$ & & \\
\hline $\begin{array}{l}\text { Carr and Tah } \\
(2001)\end{array}$ & $\begin{array}{l}\text { Complexity in risks' relationships and their consequences } \\
\text { in risk assessment which highly influence organisations' } \\
\text { performance. }\end{array}$ & & & $\checkmark$ \\
\hline $\begin{array}{l}\text { Frimpong et al. } \\
(2003)\end{array}$ & $\begin{array}{l}\text { The poor degree of experience in techniques and inability } \\
\text { to recognise the advantages of the process are the most } \\
\text { influential factors. }\end{array}$ & $\checkmark$ & & \\
\hline $\begin{array}{l}\text { Lyons and } \\
\text { Skitmore (2004) }\end{array}$ & $\begin{array}{l}\text { Implementation of RM in construction organisations } \\
\text { impact by: cost and time effectiveness; } \\
\text { Human/organisational resistance; difficulty to understand } \\
\text { benefits; lack of accepted industry model; absence of } \\
\text { dedicated resources and low level of information and } \\
\text { familiarity with techniques. }\end{array}$ & $\checkmark$ & $\checkmark$ & $\checkmark$ \\
\hline Simu (2006) & $\begin{array}{l}\text { Obstacles in RM have relations to the time effectiveness } \\
\text { and understanding outcomes. Benefits from formal RM are } \\
\text { not obvious. }\end{array}$ & & $\checkmark$ & $\checkmark$ \\
\hline Mubarak (2010) & $\begin{array}{l}\text { RM development is a time-consuming process which is } \\
\text { mostly disproportionate with projects allocated budget. }\end{array}$ & & $\checkmark$ & \\
\hline Kuang (2011) & $\begin{array}{l}\text { Time and cost constraints in construction projects prevent } \\
\text { and reduce usage of RM in organisations. }\end{array}$ & & $\checkmark$ & \\
\hline Kikwasi (2011) & $\begin{array}{l}\text { Adoption of RM in organisations influence by: inadequate } \\
\text { RM approach, reluctance of consultants to practise RM } \\
\text { and lack of knowledge. }\end{array}$ & $\checkmark$ & & $\checkmark$ \\
\hline $\begin{array}{l}\text { Chileshe and } \\
\text { Kikwasi (2013) }\end{array}$ & $\begin{array}{l}\text { The most significant difficulties are low level of } \\
\text { awareness, lack of experience and lack of information. }\end{array}$ & $\checkmark$ & & \\
\hline $\begin{array}{l}\text { Hwang et al. } \\
\text { (2014) }\end{array}$ & $\begin{array}{l}\text { The prominent challenges in RM are: lack of time, lack of } \\
\text { budget, low profit margin and uneconomical character. }\end{array}$ & & $\checkmark$ & \\
\hline
\end{tabular}

The survey-based studies by Teo et al. (1991), Bowen (1993) and Liu and Cheung (1994) explained that the reluctance of organisations in implementation of RM is mainly related to professionals' inadequate level of knowledge in: risk identification, risk analysing techniques, risk responses and communication. Chapman (1994) and Couillard (1995) added that, even management with frequent use of RM find it difficult to understand the rational for and formal process of RM in new projects. Diversity in parties' perceptions in a construction project invites undesirable biases in decision making which makes the process of managing risk more complicated and unacceptable (Liu and Cheung, 1994). Researchers such as Pasquire (1996), Akintoye and MacLeod (1997), Amos and Dent (1997) and Carr and Tah (2001) indicated that a small number of organisations practise formal RM systems with analytical approaches in assessing risks. They identified the "human problem" which is 
associated with knowledge, experience and behaviour of the key players as an initial barrier for RM implementation in the construction industry.

Akintoye and MacLeod (1997), Lyons and Skitmore (2004), Simu (2006) and Kuang (2011) examined the impact of projects' characteristics on RM implementation in construction enterprises. They highlighted that, in the construction industry which is structured around PBOs, the time commitment is associated with various aspects of risk identification and analysis. Akintoye and MacLeod (1997) evaluated that organisations in construction industry infrequently practise formal RM due to the projects' just-in-time characteristics. Further, Lyons and Skitmore (2004) through a survey in the Queensland construction engineering industry expressed the "organisation problem" as the key factor that prevents construction organisations from RM. They identified both lack of time and lack of dedicated resources as additional barriers to RM adoption. Mubarak (2010) and Hwang et al. (2014) also confirmed that the development of a RM framework is a time-consuming process which is sometimes disproportionate to projects' allocated budgets.

The most recent studies within the context of developing countries indicated that the lack of awareness of RM process, lack of experience and inadequate information are the most significant challenges which affect the implementation and practise of RM in the construction industry (Kim and Bajaj, 2000; Frimpong et al., 2003; Kikwasi, 2011; Chileshe and Kikwasi, 2013; Hwang et al., 2014). However, in contrast, "time and resources constraints" were ranked least important. Kim and Bajaj (2000) and Frimpong et al. (2003) specified that the low level of familiarity with techniques and inability to recognise the benefits of the process were the most influential factors which impact the adoption of RM. Debrah and Ofri (2005) stated that due to the manpower size of small- and medium-sized organisations in the industry they mostly suffer from inadequacy of facilities to provide RM training. This is also compounded by the absence of holistic approach for RM in standards and professional bodies which makes both understanding and implementation of RM more complicated (Kikwasi, 2011).

\section{Methodology}

This research was part of a mixed method study which aimed to identify key difficulties in RM implementation in SMEs in the UK construction industry. Findings of this paper can be used to develop a new scaling process to facilitate RM for SMEs. The overall study was based on a sequential explanatory mixed method and included quantitative and qualitative 
studies (Cameron, 2009). The mixed method was employed because neither quantitative nor qualitative methods alone were adequate to capture and assess the challenges, barriers and depth of understanding in the area under investigation (Ivankova et al., 2006). This paper embraces the quantitative part of the study which is based on a literature review and a questionnaire survey. This part assisted to conduct semi-structured interviews for further qualitative research.

\subsection{Research motivation}

There is a lack of research in RM implementation in SMEs and few academic studies have addressed the challenges of the process. In the oil industry Carter (1972) identified key barriers which large companies could experience in risk analysis, and categorised them into: human and organisational problems. Clink (2001) and Henschel (2007) assessed RM in terms of organisational behaviour and strategy formulation in different industries. In the construction industry, Kirytopoulos et al. (2001) and Simu (2006) continued the RM study within the projects' network and measured the operational obstacles and drivers. Hence, to facilitate RM implementation among SMEs, the key difficulties in this process within the construction industry were evaluated.

The data for the study was obtained by means of a postal questionnaire. Organisations which participated in this study employed more than ten people but less than 250 employees. The database for the study was extrapolated from the: Office of National Statistics (ONS); the Small Business Gateway (2014); Financial Analysis Made Easy (FAME); the Chartered Institute of Building Services Engineering (CIBSE); and the Scottish Centre for the Built Environment (SCBE). The period of the study was from the 15 of February to the 31 of May 2013. In total, 113 small and 40 medium-sized enterprises participated in this study (Figure 1). Samples were drawn across architecture, engineering and construction organisations.

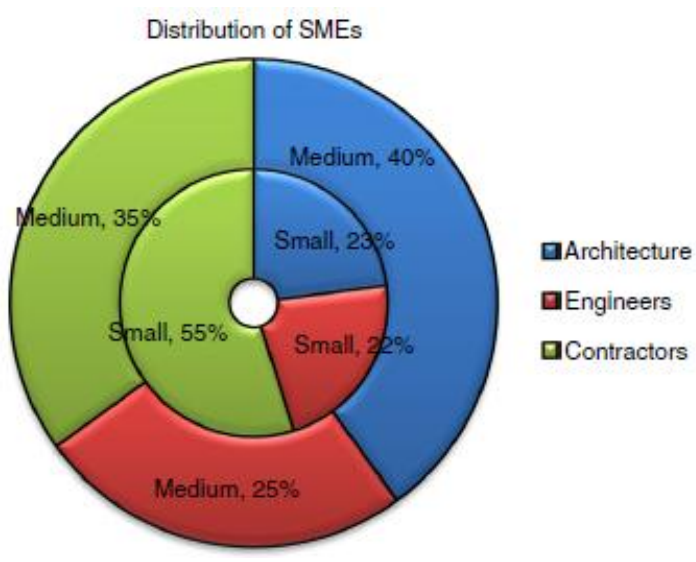


Figure 1: SMEs distribution in the construction industry that participated in the research

\subsection{Research questionnaire}

Based on existing literature (Table I) 12 variables were designed to evaluate the difficulties in RM implementation within SMEs (Table II). This provided the opportunity to clarify the content of the literature review results and recognise details behind the key issues. This also added breadth to the research and formed the basis of the semi-structured interviews for the further qualitative part of the mixed method. The questionnaire was tested and amended based on feedback received from three academics and three industrial practitioners during the pilot study. It was also revised according to the suggestions from the senior training coordinator of the National Construction College.

The questionnaire included general SMEs details with risk and risk management information. Section 1 covered the firms' size and role in the current or most recent project. In Section 2, questions were asked about the firms' RM strategy and difficulties in terms of the implementation of RM on five-point scale from "Not important at all" to "Very important". The final section assessed the most common risk categories among SMEs and measured the involved risks in organisations from "Not involved at all" to "Highly involved".

\section{Table 2: Involved Variables in RM Implementation}

\begin{tabular}{|l|c|c|c|}
\hline \multicolumn{1}{|c|}{ Involved Variables } & people & organisation & Process \\
\hline $\begin{array}{l}\text { - Managerial awareness and/or support on risk } \\
\text { management procedures }\end{array}$ & $\checkmark$ & & \\
\hline - The process of risk management & & & $\checkmark$ \\
\hline - Investment on technology and training & & $\checkmark$ & \\
\hline - Benefits of the process & $\checkmark$ & & $\checkmark$ \\
\hline - Low degree of mandatory for risk management process & & & $\checkmark$ \\
\hline $\begin{array}{l}\text { - The creation of an appropriate culture for risk } \\
\text { management }\end{array}$ & $\checkmark$ & & \\
\hline $\begin{array}{l}\text { - The adoption of appropriate tools and techniques for risk } \\
\text { management }\end{array}$ & & $\checkmark$ & \\
\hline - Time effectiveness & & $\checkmark$ & \\
\hline - Cost effectiveness & & $\checkmark$ & \\
\hline - High turnover of employees & & $\checkmark$ & \\
\hline - Skilled personnel & $\checkmark$ & & \\
\hline - Personal ownership & & & \\
\hline
\end{tabular}

\subsection{Statistical analysis}


The research questionnaire was collected by post and electronic mailing system. The data were then transferred to the Excel spread sheets and analysed by adopting Statistical Package for the Social Sciences (SPSS) version 19. The main part of the variables included in the questionnaire is used to conduct factor analysis. Factor analysis is a multivariate statistical approach and is designed for data exploration (Williams et al., 2010). This technique helped to condense the set of difficulties in RM implementation in SMEs through the following steps:

(1) assessment of the suitability of the data for factor analysis;

(2) factor extraction; and

(3) factor rotation and interpretation.

(1) Assessment of the suitability of the data for factor analysis. Prior to factor analysis all 12 variables of difficulties (Table II) in RM implementation were tested for outliers and factorability. First, the strength of the inter-correlations among the difficulties was assessed by the correlation matrix. According to the SPSS guideline the matrix of correlations should illustrates at least some correlations above 0.3. Outcomes of the research identified considerable amount of coefficients equal to 0.3 or above. Second, the result of KaiserMeyer-Olkin (KMO) test for all the 12 difficulties was 0.753 (Table III) which is acceptable for factor analysis (Tabachnick and Fidell, 2007). Finally, the Bartlett's test of the sphericity outcome in this research is $\rho=0.00$ which should be statistically significant at $\rho 00.05$ (Bartlett, 1954) (Table III). From the test results it was manifested that they all satisfied all the assumptions of the factor analysis. Similar research methodology was used for exploring critical success factors for partnering in construction projects (Chan et al., 2004).

Table III: Kaiser-Meyer-Olkin (KMO) and Bartlett's Test

\begin{tabular}{|l|l|r|}
\hline \multicolumn{2}{|l|}{ Kaiser-Meyer-Olkin Measure of Sampling Adequacy. } & $\mathbf{. 7 5 3}$ \\
\hline Bartlett's Test of Sphericity & Approx. Chi-Square & 727.724 \\
\cline { 2 - 3 } & df & 66 \\
\cline { 2 - 3 } & Sig. & $\mathbf{. 0 0 0}$ \\
\hline
\end{tabular}

(2) Factor extraction. Factor analysis is used to determine the smallest number of factors that are required to represent the interrelationships among the set of variables (Thompson, 2004). This process was obtained by the Principle Components Analysis (PCA) technique. The PCA 
is the defaultmethod inmost statistical analysing programmes and is common in factor analysis to identify underlying factors (Thompson, 2004). In this study, three techniques which include: Kaiser's criterion (Kaiser, 1960), scree-plot test (Cattell, 1966) and parallel analysis (Horn, 1965) were conducted to determine the smallest number of factors that are required for factor analysis:

(1) Kaiser's criterion: in total variance explained table from factor analysis (Table IV) in column initial eigenvalues the values above 1 highlight the number of factors $(4.248,1.634$, 1.198 and 1.062). These four factors define the number of factors that are required for factor analysis.

(2) Scree-plot test: the straight red line drawn based on smaller eigenvalues in Figure 2 indicates the linearity breakpoint of the graph at component 2 . The components above the breakpoint are the number of factors which need to be considered in the research.

(3) Parallel analysis: in this method the actual eigenvalues provided in the total variance explained table (Table IV) were compared by random ordered eigenvalues which are obtained under the Monte Carlo simulation. The Monte Carlo simulation in this research was based on 12 difficulties, 153 participants and 100 sets of random numbers. Table V presents two sets of eigenvalues (actual and random). If the value from PCA (see Table V, column 1) is bigger than the value in column 2 then the component is acceptable otherwise should be rejected.

Table IV: Total Variance Explained

\begin{tabular}{|c|c|c|c|c|c|c|c|}
\hline \multirow{2}{*}{ Component } & \multicolumn{3}{|c|}{ Initial Eigenvalues } & \multicolumn{3}{|c|}{$\begin{array}{c}\text { Extraction Sums of Squared } \\
\text { Loadings }\end{array}$} & \multirow{2}{*}{$\begin{array}{c}\text { Rotation } \\
\text { Sums of } \\
\text { Squared } \\
\text { Loadings } \\
\\
\text { Total }\end{array}$} \\
\hline & Total & $\begin{array}{c}\% \text { of } \\
\text { Variance }\end{array}$ & $\begin{array}{c}\text { Cumulative } \\
\%\end{array}$ & Total & $\begin{array}{c}\% \text { of } \\
\text { Variance }\end{array}$ & $\begin{array}{c}\text { Cumulative } \\
\%\end{array}$ & \\
\hline 1 & 4.248 & 35.397 & 35.397 & 4.248 & 35.397 & 35.397 & 3.350 \\
\hline 2 & 1.634 & 13.614 & 49.011 & 1.634 & 13.614 & 49.011 & 2.388 \\
\hline 3 & 1.198 & 9.986 & $\begin{array}{l}58.997 \\
\end{array}$ & 1.198 & 9.986 & 58.997 & 2.758 \\
\hline 4 & 1.062 & 8.854 & 67.850 & 1.062 & 8.854 & 67.850 & 1.832 \\
\hline 5 & .868 & 7.237 & 75.087 & & & & \\
\hline 6 & .711 & 5.926 & 81.013 & & & & \\
\hline 7 & .696 & 5.802 & 86.814 & & & & \\
\hline 8 & .499 & 4.157 & 90.972 & & & & \\
\hline 9 & .383 & 3.193 & 94.164 & & & & \\
\hline 10 & .355 & 2.954 & 97.119 & & & & \\
\hline
\end{tabular}




\begin{tabular}{|l|r|r|r|r|r|r|l|}
11 & .220 & 1.833 & 98.952 & & & & \\
\hline 12 & .126 & 1.048 & 100.000 & & & & \\
\hline
\end{tabular}

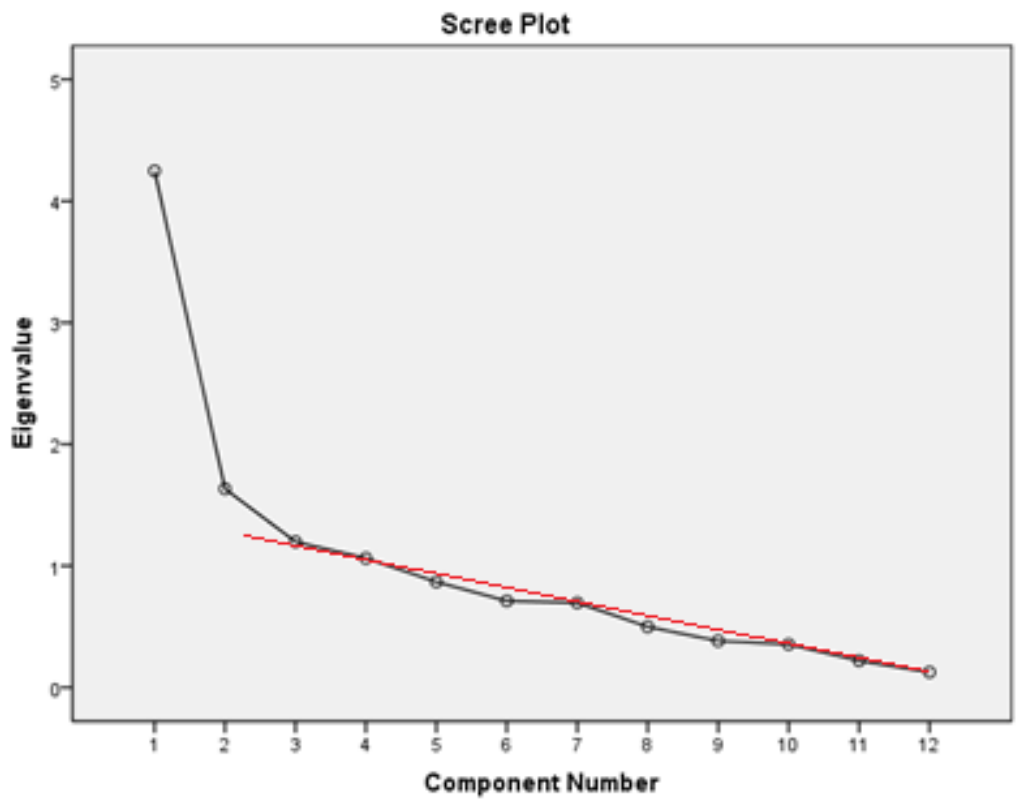

Figure 2: Scree-Plot

Table V: Comparison of Actual Eigenvalues from PCA and Criterion Values from Parallel Analysis

\begin{tabular}{|c|c|c|c|}
\hline $\begin{array}{c}\text { Component } \\
\text { Number }\end{array}$ & $\begin{array}{c}\text { Actual Eigenvalue } \\
\text { from PCA }\end{array}$ & $\begin{array}{c}\text { Criterion Value } \\
\text { from Parallel } \\
\text { Analysis }\end{array}$ & Decision \\
\hline 1 & 4.248 & 1.4938 & Accept \\
\hline 2 & 1.634 & 1.3482 & Accept \\
\hline 3 & 1.198 & 1.2528 & Reject \\
\hline 4 & 1.062 & 1.1655 & Reject \\
\hline 5 & 0.868 & 1.0862 & Reject \\
\hline
\end{tabular}

According to the above techniques two-factor solution for the factor analysis method was considered to extract the key difficulties in RM (Table VI).

Table VI: Number of Factors to retain in the PCA

\begin{tabular}{|l|c|c|}
\hline \multicolumn{1}{|c|}{ Technique } & $\begin{array}{c}\text { Number of } \\
\text { Factors }\end{array}$ & $\begin{array}{c}\text { Cumulative } \\
\text { Variance } \\
\%\end{array}$ \\
\hline $\begin{array}{l}\text { Kaiser's Criterion (Total Variance Explained) } \\
\text { (Table 5) }\end{array}$ & 4 & 49.01 \\
\hline Scree-plot (Figure 2) & 2 & 49.01 \\
\hline
\end{tabular}


(3) Factor rotation and interpretation. the two-factor solution proved a total of 49.01 per cent of the variance (component 1: 35.39 per cent and component 2: 13.61 per cent - Table IV, cumulative column). To aid in the interpretation of these two components, Oblimin Rotation (Costello and Osborne, 2005) was performed. This process highlighted the highest loading difficulties which include: adopt an appropriate process (scaling RM); adopt appropriate tools and techniques; cost effectiveness; and creation of an appropriate culture of RM and lack of managerial awareness (highlighted items in Table VII).

Table VII: Pattern and Structure Matrices for PCA with Oblimin Rotation of Two Factor Solution of Difficulties to Implement RM

\begin{tabular}{|c|c|c|c|c|c|}
\hline \multirow{3}{*}{ Difficulties } & \multicolumn{2}{|c|}{ Pattern Coefficients } & \multicolumn{2}{|c|}{ Structure Coefficients } & \multirow{3}{*}{ Ranking } \\
\hline & \multicolumn{2}{|c|}{ Component } & \multicolumn{2}{|c|}{ Component } & \\
\hline & 1 & 2 & 1 & 2 & \\
\hline $\begin{array}{l}\text { Adopt an appropriate } \\
\text { process-scaling RM process }\end{array}$ & .871 & -.096 & .833 & .251 & 1 \\
\hline $\begin{array}{l}\text { Adopt appropriate tools and } \\
\text { techniques }\end{array}$ & .809 & -.099 & .869 & .263 & 2 \\
\hline $\begin{array}{l}\text { Creation of an appropriate } \\
\text { culture for RM }\end{array}$ & .789 & -.017 & .782 & .297 & 4 \\
\hline $\begin{array}{l}\text { Lack of managerial } \\
\text { awareness }\end{array}$ & .586 & .074 & .615 & .307 & \\
\hline $\begin{array}{l}\text { Shortage of experienced } \\
\text { personnel }\end{array}$ & .491 & .220 & .578 & .415 & \\
\hline Cost effectiveness & -.072 & .860 & .278 & .851 & 3 \\
\hline Time effectiveness & -.057 & .548 & .280 & .525 & \\
\hline High turnover of employees & .032 & .633 & .284 & .646 & \\
\hline Personal ownership & -.087 & .469 & .477 & .549 & \\
\hline Lack of investment & .147 & .437 & .468 & .546 & \\
\hline Intangible benefits & .298 & .428 & .321 & .496 & \\
\hline $\begin{array}{l}\text { Low degree of mandatory for } \\
\text { RM }\end{array}$ & .308 & .427 & .100 & .434 & \\
\hline
\end{tabular}




\section{1) Adopt an appropriate process - scaling risk management}

The first important difficulty was the adaption of RM to meet SMEs' preferences. About 97 per cent of respondents indicated this difficulty due to the inability to understand to what extent RM needs to be conducted within dedicated resources to protect business activities. Lack of adjusting skills and knowledge to integrate businesses' missions and visions with $\mathrm{RM}$ process identified as the most fundamental issue that hinders SMEs to practise this part of the management.

\section{2) Adopt appropriate tools and techniques for RM}

The adoption of appropriate tools and techniques for RM was highlighted as the second important difficulty for SMEs in the RM implementation process. In total, 148 organisations out of 153 considered this difficulty as the most organisational challenges due to the unfamiliarity with the efficiency of different types of tools/ techniques, which stems from the lack of requisite knowledge and rapid developments in technology. Totally, 26 participants in this study stated that the decision to select tools or techniques for assessing risks was the most complicated part of the process for them, because they found it hard to understand which tool could obtain the best results according to their preferences. Moreover, more than 57 per cent of respondents cited financial issue as a challenge to adopting appropriate tools and techniques.

\section{3) Cost effectiveness}

The third factor highlighted by approximately 90 per cent of the SMEs in this survey was the costs of implementation and practise of RM. The majority of SMEs indicated that they are not interested in capital investment in unclear systematic practise of management processes such as RM.

\section{4) The creation of an appropriate culture for $R M$}

The fourth key difficulty was the "an appropriate culture for practising risk management". 146 organisations named the financial barrier as the major factor which influences the organisational decision making in the implementation of risk management. In total, seven participants in this study indicated that they did not believe in the advantages of risk management and hence considered investment in this particular area as a total loss.

\section{Discussion of factor analysis results}


The findings of the study were consistent with the outcomes of previous researches (Ward et al., 1991; Sparrow and Bentley, 2000; Simu, 2006; Henschel, 2007) which indicated that the size of organisation influences the implementation and practice of RM. The findings highlighted that the implementation of RM within SMEs is influenced by two main integrated difficulties which are directly determined by the organisational characteristics. These difficulties include: scaling risk management, and tools and techniques adoption.

\subsection{Difficulty 1: Scaling Risk Management}

The most important difficulty which discourages SMEs in RM implementation in the UK construction industry is inability to scale the process within organisation. SMEs stressed the difficulty on how to adapt and prioritise the vast range of probabilities with key business objectives in respect of resources. The difficulty is further heightened by the fact that RM is continually updating and evolving.

SMEs' management must endorse the principles of RM consistently and are responsible to ensure that there is a fit-for-purpose RM framework in place. The study indicated that the management poor documentation; lack of knowledge and skill; and absence of awareness affect RM. Simu (2006) explained that in small businesses in construction industry the managers' minimum documentation process causes a poor return of experience in the organisation. This poor return of experience from lessons learnt impact the organisational knowledge memory (Egbu, 2000) and pose difficulty to understand how to apply the RM theory in practice (Carter, 1972). Moreover, inability of prioritising objectives and relatively activities of the organisation due to the lack of understanding in tendencies is the second managerial challenge in RM process. SMEs' managers need to know how and to what extent they are willing to protect the organisational priorities and which strategy could address the ideal vision. Majority of SMEs as a result of insufficient knowledge and skills have difficulty to articulate a strategy which could meet requirements and preferences with a touch of reality (Wang et al., 2007).

Establish a balance between the organisational resources, preferences and requirements is the second difficulty which affects the scaling RM process. To achieve a reasonable balance, enterprises need to evaluate their organisational available assets and capability. This process need to be accomplished by management planning with adequate allocation of time and budget. SMEs' due to the limited resources and less ability in capital investment have difficulty in planning to use of information (Ghobadian and Gallear, 1997). Therefore, with 
lack of planning to identify capability of the organisation in the process of RM the understanding of the outcomes is extremely difficult. Also, managers in small enterprises believe that the charges of expert employees, programme and computer systems for RM are additional costs which cannot be justified based on their businesses size (Deakins and Bentley, 1995; Clink, 2001). Deshpande et al. (1986) proved that the organisation needs to possess necessary human resources with adequate level of education to facilitate systematic process. Hence, SMEs are under pressure by low level of investment in training and consultancy to scale RM.

\subsection{Difficulty 2: Tools and Techniques Adoption}

The difficulty to understand which tool or technique could support RM process to meet the organisation's objectives is an additional process barrier in RM implementation. The research result indicates that factors in this difficulty are related to the attitude and knowledge of individuals within organisations. Lyons and Skitmore (2004) specified that the attitude of people in an organisation determines the implementation of a technique. Sparrow and Bentley (2000) by focus on SMEs evaluated that the take-up tools and techniques in RM are directly depended on the entrepreneurs' attitude. SMEs usually due to inability to understand the procedure (that needs to be employed to make a technique work) and the type of outcomes that could be obtain, are reluctant to develop a technique to exactly fit to their needs (Leopoulos et al., 2006). This issue was authenticated by Simu (2006), Leopoulos et al. (2006) and Chapman and Ward (2011) who highlighted the reaction and resistance of users in RM process in organisations. Moreover, the lack of knowledge among SMEs identified as the second factor in adoption of tools and techniques. There is evidence that shows the managers decision related to their knowledge (Sparrow and Bentley, 2000). Hence, the difficulty to recognise the ranges of outcomes from managing risk techniques which is emphasised by most of SMEs averts of adoption of the process. In addition, due to the limited budget for training in RM to compare tools and techniques, SMEs suffer from employment of the most relevant tool or technique to extract the best possible outcomes.

\section{Limitations}

While the research provides a number of notable contributions to RM implementation in both theory and practice, several limitations of the research need to be acknowledged. First, the study did not distinguish between SMEs. The organisations' characteristics such as the number of employees, their age and skills levels can affect the initiation and implementation 
of RM. Medium-sized companies with adequate level of resources have fewer barriers in RM implementation, whereas small-sized enterprises generally suffer from a lack of resources and knowledge. In addition, from the perspective of the organisations' field of practice, the research did not classify them in terms of the types of enterprises (i.e. contractors/subcontractors, engineers and architectures). Second, the sample included SMEs from the UK construction industry, and hence its results may not directly apply to other industries or similar organisations operating in other countries. The third limitation is the relatively small sample size. A larger sample could produce different results by addressing multiple class sections. Future studies should focus on a specific category (i.e. micro-, small- or mediumsized enterprises) and employ a larger number of cases representing the population of interest, in order to obtain more detailed information. However, in spite of these limitations, the findings of the study indicated the main difficulties in RM implementation, which were consistent with the outcomes of the literature review (Table I).

\section{Conclusion}

The research investigated the difficulties in RM implementation among constructional related SMEs in the UK. In the quest to investigate the factors for low level uptake of RM implementation, "scaling RM process", "tools and techniques adoption", "cost effectiveness" and "inappropriate culture of practising" were the key important challenges that the UK organisations need to overcome. There is no shortage of literature on the topic of RM, but none of the standards and professional bodies explain the fundamental principles of applying RM to the situations that SMEs could find themselves in. In order to raise the level of implementation and practise of RM, there is a need to develop a fit-for-purpose RM framework for addressing the balance between preferences, requirements and resources within SMEs in the construction industry. This framework needs to regulate the risk analysis outcomes with organisational objectives by employing appropriate tools and techniques. Also, it should decrease the costs of managing risk process to satisfy and encourage senior management and relevant stakeholders within the construction industry.

This research explored a set of difficulties for RM implementation within construction SMEs. This research provides insight into the understanding of the difficulties, which influence the adoption of RM for construction projects. It also expands the attempts made on studying and assessing the challenges in developing organisational performance which consequently impact the economy in general and the UK economy in particular. This research helps British 
businesses to improve their risk management processes and thereby compete in tough business environments, and take better advantage of opportunities. Finally, this research provides a contribution to the body of knowledge on the RM subject which was an unexplored context.

\section{References}

Akintoye, A.S. and MacLeod, M.J. (1997), "Risk analysis and management in construction", International Journal of Project Management, Vol. 15 No. 1, pp. 31-38.

Amos, J. and Dent, P. (1997), "Risk analysis and management for major construction projects", Proceedings: Royal Institution of Chartered Surveyors COBRA Conference (Construction Procurement Theme), Portsmouth, 10-12 September.

Association for Project Management (APM) (2013), Project Risk Analysis and Management Guide, 2nd ed., Hobbs the Printers, Hampshire.

Bartlett, M.S. (1954), "A note on the multiplying factors for various chi-square approximations", Journal of the Royal Statistical Society, Vol. 16, No. 2, pp. 296-298.

Birnie, J. (1993), "A behavioural study using decision analysis of building cost prediction by chartered quantity surveyors", D.Phil. thesis, University of Ulster, Jordanstown.

Bowen, P., Pearl, R. and Edwards, P. (1999), "Client briefing process and procurement method selection: a South African study, engineering, construction", Architectural Management, Vol. 6 No. 2, pp. 91-104

Bowen, P.A. (1993), “A communication-based approach to price modelling and price forecasting in the design phase of the traditional building procurement process in South Africa", Ph.D thesis, University of Port Elizabeth, Port Elizabeth.

British Standard (BS 31100) (2008), Risk Management-Code of Practice, BSI British Standard.

Burtonshaw-Gunn, S.A. (2009), Risk and Financial Management in Construction, Construction Risk Management, Gower Publishing Limited, Farnham.

Cameron, R. (2009), “A sequential mixed model research design: design, analytical and display issues", International Journal of Multiple Research Approaches, Vol. 3 No. 2, pp. 140-152.

Carr, V. and Tah, J.H.M. (2001), “A fuzzy approach to construction project risk assessment and analysis: construction project risk management system", Advance in Engineering Software, Vol. 32 Nos 10-11, pp. 847-857.

Carter, E.E. (1972), "What are the risks in risk analysis?", Harvard Business Review, Vol. 50 No. 4, pp. 72-82.

Cattell, R.B. (1966), "The scree test for number of factors", Multivariate Behavioural Research, Vol. 1 No. 2, pp. 245-276.

Chan, A., Chan, D., Chiang, Y., Tang, B., Chan, E. and Ho, K. (2004), "Exploring critical success factors for partnering in construction projects", J. Constr. Eng. Manage, Vol. 130 No. 2, pp. 188-198.

Chapman, C. and Ward, S. (2011), "How to manage project opportunity and risk", in Nichols, M. (Ed.), Why Uncertainty Management Can Be A Much Better Approach Than Risk Management, 3rd ed., John Wiley \& Sons Ltd, West Sussex, p. 520.

Chapman, C.B. (1994), "Risk analysis and inherent risk management priorities", in Shaughnessy, H. (ed.), Collaboration Management: New Project and Partnering Techniques, John Wiley \& Sons, Chichester, pp. 107-128. 
Chartered Institute of Building (CIOB) (2010), “The thinking man's industry", available at: www.construction-manager.co.uk//news/thinking-mans-industry/ (accessed 21 January 2013).

Chartered Institution of Building Services Engineers (CIBSE) (2012), available at: www.cibse.org/ (accessed 10 February 2013).

Chileshe, N. and Kikwasi, G.J. (2013), "Perception of barriers to implementing risk assessment and management practices by construction professionals in Tanzania", 29th Annual ARCOM Conference, Reading, pp. 1137-1146.

Clink, S. (2001), "Risk management in small business", PhD thesis, Glasgow Caledonian University, p. 52.

Cooke-Davies, T. (2002), "The 'real' success factors on projects", International Journal of Project Management, Vol. 20 No. 3, pp. 185-190.

Costello, A.B. and Osborne, J.W. (2005), "Best practices in exploratory factor analysis: four recommendations for getting the most from your analysis", Practical Assessment, Research \& Evaluation, Vol. 10 No. 7, pp. 1-9.

Couillard, J. (1995), "The role of project risk in determining project management approach", Project Management Journal, Vol. 26 No. 4, pp. 3-15.

Deakins, D. and Bentley, P. (1995), "Risk, insurance and high technology small firms", Journal of Society of Fellows, Vol 9 No. 2, pp. 43-55.

Debrah, Y.A. and Ofori, G. (2005), "Emerging managerial competencies of professionals in the Tanzanian construction industry", The International Journal of Human Resource Management, Vol. 16 No. 8, pp. 1399-1414.

Department for Business Innovation and Skills (BIS) (2013), available at: www.ons.gov.uk/ons/dcp171778_348092.pdf (accessed 13 February 2014).

Deshpande, A.B., Dusting, F.J.P. and Younger, A. (1986), “Aco-operation quality management system for small companies", International Journal of Quality \& Reliability Management, Vol. 3 No. 1, pp. 38-47.

Egbu C.O. (2000), "Knowledge management in construction SMEs: coping with the issues of structure, culture, commitment and motivation", 16th Annual ARCOM Conference, Vol. 1, pp. 83-92.

Financial Analysis Made Easy (FAME) (2012), “A financial database of major public and private British companies", available at: http://fame.bvdinfo.com/ (accessed 1 February 2013).

Flanagan, R. and Norman, G. (1993), Risk Management and Construction, Blackwell Scientific, Oxford; Boston, MA.

Frimpong, Y., Oluwoye, J. and Crawford, L. (2003), "Causes of delay and cost overruns in construction of groundwater projects in a developing countries, Ghana as a case study", International Journal of Project Management, Vol. 21 No 5, pp. 321-326.

Ghobadian, A. and Gallear, D. (1997), "TQM and organisation size”, International Journal of Operations and Production Management, Vol. 17 No. 2, pp. 121-163.

Gidado, K.I. (1996), "Project complexity: the focal point of construction production planning", Construction Management and Economics, Vol. 14 No. 3, pp. 213-225.

Green, S., Newcombe, R., Fernie, S. and Weller, S. (2004), Learning Across Business Sector: Knowledge Sharing Between Aerospace And Construction, University of Reading, Reading.

Henschel, T. (2007), "Risk Management Practices in the Main Industries of German Small to Medium-Sized Enterprises, An Empirical Investigation”, PhD thesis, Napier University, Edinburgh.

Hobday, M. (2000), "The project-based organisation: an ideal form for managing complex products and systems?”, Research Policy, Vol. 29 Nos 7-8, pp. 871-893. 
Horn, J.L. (1965), "A rationale and test for the number of factors in factor analysis", Psychometrika, Vol. 30 No. 2, pp. 179-185.

Hwang, B.G., Zhao, X. and Toh, L.P. (2014), "Risk management in small construction projects in Singapore: status, barriers and impact", International Journal of Project Management, Vol. 32 No. 1, pp. 116-124.

Ivankova, N., Creswell, J.W. and Stick, S. (2006), "Using mixed-methods sequential explanatory design: from theory to practice", Field Methods, Vol. 18 No. 1, pp. 3-20.

Kaiser, H. (1960), "The application of electronic computers to factor analysis", Educational and Psychological Measurement, Vol. 20, pp. 141-151.

Kikwasi, G.J. (2011), “An assessment of risk management practices by consultants in Tanzania", Proceeding of the 6th Built Environment, Johannesburg.

Kim, S. and Bajaj, D. (2000), "Risk management in construction: an approach for contractors in South Korea", Cost Engineering, Vol. 42 No. 1, pp. 38-44.

Kirytopoulos, K., Leopoulos, V. and Malandrakis, C. (2001), "Risk management: a powerful tool for improving efficiency of project oriented SMEs", SMESME International Conference, pp. 331-339.

Kuang, Z. (2011), Risk Management In Construction Projects, University College, Horsens Campus, Horsens.

Leopoulos, V.N., Kirytopoulos, K.A. and Malandrakis, C. (2006), "Risk management for SMEs: tools to use and how", Production Planning and Control, Vol. 17 No. 3, pp. 322332.

Liu, A.M.M. and Cheung, S.O. (1994), "Perceptions of risk distribution in construction contracts" in Rowlinson, S. (Ed.), Proceedings: CIB (Conseil International du BaÃtiment) International Symposium. Commission W92 Procurement Systems "East Meets West", Department of Surveying, University of Hong Kong, Hong Kong, pp. 35-42.

Lyons, T. and Skitmore, M. (2004), "Project risk management in the queensland engineering construction industry: a survey", International Journal of Project Management, Vol. 22 No. 1, pp. 51-61.

Mak, S.W. (1995), "Risk analysis in construction: a paradigm shift from a hard to soft approach", Construction Management and Economics, Vol. 13 No. 5, pp. 385-392.

Mak, S.W. and Raftery, J. (1992), "Risk attitude and systematic bias in estimating and forecasting: an empirical study", Construction Management and Economics, Vol. 10 No. 4, pp. 303-320.

McKim, R.A. (1991), "Risk behaviour/risk allocation and contract strategy" in Bezelga, A. and Brandon, P. (Eds), Management, Quality and Economics in Building, E. \& F. N. Spon, London, pp. 199-206.

McKim, R.A. (1992), "Risk behaviour of contractors: a Canadian study", Project Management Journal, Vol. 23 No. 3, pp. 51-55.

Mills A. (2001), "A systematic approach to risk management for construction", Structural Survey, Vol. 19 No. 5, pp. 245-252.

Mubarak S. (2010), Construction Project Scheduling and Control, John Wiley \& Sons, New York, NY.

OECD (2005), The Measurement of Scientific and Technological Activities: Guidelines for Collecting and Interpreting Innovation Data: OSLO Manual, 3rd ed. Working Party of National Experts on Scientific and Technology Indicators, OECD, Paris, para. 177.

Office of National Statistics (ONS) (2012), available at www.statistics.gov.uk/hub/index.html (accessed 2 February 2013).

Pasquire, C. (1996), "Risk management strategies for enhancing contractors' tendering", in Taylor, R. (Ed.), Proceedings: CIB (Conseil International du BaÃtiment) International 
Symposium-"North Meets South". Commission W92- Building Procurement Systems, University of Natal, Durban, pp. 501-511.

Perry, J.H. and Hayes, R.W. (1985), "Risk and its management in construction projects", Proceedings of the Institution of Civil Engineering, Vol. 78 No. 3, pp. 499-521.

Raftery, J. (1994), "Human aspects of project risk management", in Rowlinson, S. (Ed.), Proceedings: CIB (Conseil International du BaAtiment) International Symposium. Commission W92 Procurement Systems East Meets West, Department of Surveying, University of Hong Kong, Hong Kong, pp. 277-286.

Raghavan, R.S. (2005), Chartered Accountant Report, available at: http://220.227.161.86/10412528-535.pdf (accessed 29 January 2014).

Rounds, J. and Segner, R.O. (2011), "Construction supervision, competition, risk, and construction company failure", John Wiley \& Sons, Hoboken, NJ, p. 171

Simu, K. (2006), "Risk Management in Small Construction Projects", Licentiate thesis, Department of Civil and Environmental Engineering, Luleå tekniska universitet, Luleå./Luleå University of Technology.

Small Business Gateway (2014), available at: www.statistics.gov.uk/hub/index.html (accessed 1 February 2013).

Sparrow, J. and Bentley, P. (2000), "Decision tendencies of entrepreneurs and small business risk management practices", Risk Management, An International Journal, Vol 2 No. 1, pp. 17-26.

Tabachnick, B.G. and Fidell, L.S. (2007), Using Multivariate Statistics, 5th Edition, Pearson Education, Boston, MA.

Teo, D.H.P., Quah, L.K., Torrance, V.B. and Okoro, M.I. (1991), "Risk evaluation and decision support system for tendering and building in refurbishment contracts", in Bezelga, A. and Brandon, P. (Eds), Management, Quality and Economics in Building, E. \& F. N. Spon, London, pp. 301-319.

Thompson, B. (2004), Exploratory And Confirmatory Factor Analysis: Understanding Concepts And Applications, American Psychological Association, Washington, DC.

Turner, J.R. (1999), "The handbook of project-based management: improving the processes for achieving strategic objectives", 2nd ed., Mc Graw-Hill, London. p. 529.

Vargas-Hernandez, J.G. (2011), "Modelling risk and innovation management", Advances in Competitiveness Research, Vol. 19 Nos 3-4, pp. 45-57.

Verbano, C. and Venturini, K. (2013), "Managing risks in SMEs: a literature review and research agenda", Journal of Technology Management \& Innovation, Vol. 8 No. 3, pp. 186-197.

Voetsch, R.J., Cioffi, D.F. and Anbari, F.T. (2004), "Project risk management practices and their association with reported project success", Proceedings from IRNOP, Turku, 15-27 August.

Walker A. (1996), Project Management In Construction, Blackwell, Oxford.

Wang, C., Walker, E.A. and Redmond, J.L. (2007), "Explaining the lack of strategic planning in SMEs: the importance of owner motivation", International Journal of Organisational Behaviour, Vol. 12 No. 1, pp. 1-16.

Ward, S.C., Chapman, C.B. and Curtis, B. (1991), "On the allocation of risk in construction projects", International Journal of Project Management, Vol. 9 No. 3, pp. 140-147.

Williams, B., Onsman, A. and Brown, T. (2010), "Exploratory factor analysis: a five-step guide for novices", Journal of Emergency Primary Health Care (JEPHC), Vol. 8 No. 3.

Wood, G., McDermott, P. and Swan, W. (2002), "The ethical benefits of trust-based partnering: the example of the construction industry", A Business Review, Vol. 11 No. 1, pp. 4-13. 
Yeo, K.T. and Lai, W.C. (2004), "Risk management strategies for SME investing in China: a Singapore an perspective", IEEE International Engineering Management Conference Proceedings, Singapore, pp. 794-798.

Zou Patrick, X.W., Zang, G. and Wang, J. (2006), "Identifying key risks in construction projects: life cycle and stakeholders perspectives", available at:

www.prres.net/papers/Zou_risks_in_construction_projects.pdf (accessed 20 February 2012). 